\title{
Human Leukocyte Antigen-G Inhibits the Anti-Tumor Effect of Natural Killer Cells via Immunoglobulin-Like Transcript 2 in Gastric Cancer
}

\author{
Rui Wan Zi-Wei Wang Hui Li Xu-Dong Peng Guang-Yi Liu Jun-Ming Ou \\ An-Qi Cheng
}

Department of Gastrointestinal Surgery, The First Affiliated Hospital of Chongqing Medical University, Chongqing, China

\section{Key Words}

Hla-G • ILT2 • Natural killer cell • Gastric cancer • Tumor escape

\begin{abstract}
Background/Aims: Human leukocyte antigen-G (HLA-G) plays an important role in inhibiting natural killer (NK) cell function and promoting immune escape. However, the specific mechanism of HLA-G on NK in gastric cancer (GC) remains not well understood. This study investigated the expression of HLA-G in GC and the role of HLA-G-effected NK cells in GC progression. Methods: HLA-G expression in GC tissues obtained from 49 patients with GC was analyzed by immunohistochemistry and western blot. The number of tumor-infiltrating NK cells and the expression of their surface receptors were analyzed by immunohistochemistry and flow cytometry, respectively. The effect of HLA-G on NK cell proliferation was examined by Cell Counting Kit-8 (CCK8) assay. LDH release assay was used to evaluate the effect of HLA-G on the cytotoxic activity of NK cells, and the levels of IFN- $\gamma$ and TNF- $\alpha$ in the co-cultured supernatant were detected by ELISA. Mice bearing a xenograft tumor model were used to examine the effect of HLA-G on the anti-tumor effect of NK cells. Results: HLA-G positive expression was detected in most of the GC tissues, and was correlated with the adverse prognosis of the disease. The expression of HLA-G was negatively associated with the number of tumor-infiltrating NK cells. Furthermore, GC cell lines with overexpressed HLA-G revealed their ability to inhibit the cell proliferation and cytotoxic activity of NK-92MI cells, and reduce the secretion of IFN- $\gamma$ and TNF- $\alpha$ through immunoglobulin-like transcript 2 (ILT2). Finally, this in vivo experiment was able to prove that HLA-G can inhibit the anti-tumor effect of NK cells through ILT2. Conclusion: The expression of HLA-G was strongly correlated with the adverse prognosis of GC. The reason may be that it inhibits the proliferation and cytotoxic activity of infiltrating NK cells through ILT2.




\section{Cellular Physiology Cell Physiol Biochem 2017;44:1828-1841 \begin{tabular}{l|l|l} 
and Biochemistry $\begin{array}{l}\text { DOI: 10.1159/000485819 } \\
\text { Published online: November 07, } 2017\end{array}$ & $\begin{array}{l}\text { (c) } 2017 \text { The Author(s). Published by S. Karger AG, Basel } \\
\text { www.karger.com/cpb }\end{array}$
\end{tabular}}

Wan et al.: Human Leukocyte Antigen-G Inhibits Natural Killer Cells

\section{Introduction}

Gastric cancer (GC) is considered the fifth most common malignancy worldwide [1]. In China, GC morbidity and mortality rank second among all malignant tumors [2]. Due to limited census measures, GC patients are mainly those with an advanced cancer stage. That is, the efficacy of surgical treatment is limited. In recent years, immunotherapy has become very popular for cancer treatments [3]. Compared to conventional therapies such as chemotherapy, these approach increases tumor specificity, and thereby preserves the healthy cells of the patient

Tumor cells can undergo immunoediting to survive and grow under selective pressure, eventually escaping immune surveillance [4]. Innate immune surveillance plays a key role in controlling tumor progression [5]. Natural killer (NK) cells are an important part of the innate immune system, and have a vital role during the early tumor progression phase, since they are the first defense system activated in the body [6-8]. NK cells may attach malignant cells by perforin, granzyme and IFN- $\gamma$ secretion, and through antibody-dependent cellmediated cytotoxicity (ADCC), thereby promoting lysis-mediated tumor cell death. Studies have shown that NK cell dysfunction in malignant tumors may be strongly correlated to disease progression $[9,10]$. Furthermore, several data have shown that the re-education of infiltrating NK cells can be correlated to GC biological behaviors [11-13].

Human leukocyte antigen-G (HLA-G) is a non-classical major histocompatibility complex (MHC) class I antigen. Its mRNA was confirmed in 1987 [14]. During normal physiological conditions, HLA-G is mainly expressed in trophoblast cells and immune tolerance organs [15-21]. However, under pathological conditions, an aberrant expression of HLA-G can occur, such as autoimmune diseases, infections, inflammation and tumors [22-25]. At present, HLA-G is considered an important immunosuppressive molecule in the body [26], and plays an important role in fetal-maternal immune tolerance, organ transplantation and the immune escape of tumors [27-31]. HLA-G can inhibit the function of many immune cells such as NK cells, CD4+ and CD8+ T cells, and dendritic cells (DC) by binding to cell surfaceexpressed receptors, including immunoglobulin-like transcript 2 (ILT2), ILT4 and killer cell immunoglobulin-like receptor 2DL4 (KIR2DL4) [32]. Furthermore, studies have shown that the upregulation of HLA-G expression may be one of the reasons that cause tumors to escape immune surveillance $[33,34]$. However, its exact mechanism remains not well-understood, calling for further investigations.

The present study aims to investigate the expression of HLA-G in GC, and investigate the mechanism of interaction between HLA-G and NK cells.

\section{Materials and Methods}

Patients and samples

From February 2015 to November 2016, 49 GC samples obtained from 49 GC patients and paired normal tumor-adjacent samples (at least $3 \mathrm{~cm}$ from the tumor site) were obtained from the Department of Gastrointestinal Surgery, The First Affiliated Hospital of Chongqing Medical University, China. None of the GC patients were treated with chemotherapy before the operation. Invasion depth, lymph node metastasis and clinical stages were classified according to AJCC ( $7^{\text {th }}$ edition) guidelines. The clinical characteristics of all patients are shown in Table 1 and Table 2. The last follow-up date was February 10, 2017. The use of human tissue specimens was approved by the Ethical Committee of The First Affiliated Hospital of Chongqing Medical University, and a written informed consent was obtained from each patient (Approval number: 2016-106).

\section{Immunohistochemistry}

The formalin-fixed and paraffin-embedded samples were cut into 4- $\mu \mathrm{m}$ sections, and were processed for immunohistochemistry, as previously described [35]. Incubation with anti-HLA-G (1:50; Abcam, USA; catalog number: ab52455; clone: 4H84) and anti-human CD57 (1:50; Abcam, USA; catalog number: 
Table 1. Correlation of clinicopathologic feature with HLA-G expression and tumor-infiltrating NK cells (Part I)

\begin{tabular}{|c|c|c|c|c|c|c|c|c|}
\hline \multirow{2}{*}{$\begin{array}{l}\text { Clinicopathological } \\
\text { feature }\end{array}$} & \multirow{2}{*}{$\begin{array}{c}\text { Total } \\
(\mathrm{N}=49)\end{array}$} & \multicolumn{2}{|c|}{ HLA-G expression } & \multirow[b]{2}{*}{$\chi^{2}$} & \multicolumn{2}{|r|}{$\begin{array}{l}\text { Infiltrating } \\
\text { NK cells }\end{array}$} & \multirow[b]{2}{*}{$t / F$} & \multirow[b]{2}{*}{$p$} \\
\hline & & $\begin{array}{c}\text { Negative } \\
(\mathrm{N}=19)\end{array}$ & $\begin{array}{l}\text { Positive } \\
(\mathrm{N}=30)\end{array}$ & & $p$ & mean $\pm \mathrm{SD}$ & & \\
\hline Gender & & & & \multicolumn{3}{|c|}{0.0160 .898} & -0.261 & 0.796 \\
\hline male & $33(67.35 \%)$ & $13(68.42 \%)$ & $20(66.67 \%)$ & & & $29.50 \pm 24.96$ & & \\
\hline female & $16(32.65 \%)$ & $6(31.58 \%)$ & $10(33.33 \%)$ & & & $31.36 \pm 19.99$ & & \\
\hline Age (years) & & & & 0.752 & 0.386 & & -1.757 & 0.085 \\
\hline$<60$ & $17(34.69 \%)$ & $8(42.11 \%)$ & $9(30.00 \%)$ & & & $22.26 \pm 12.00$ & & \\
\hline$\geq 60$ & $32(65.31 \%)$ & $11(57.89 \%)$ & $21(70.00 \%)$ & & & $34.28 \pm 26.69$ & & \\
\hline Tumor size $(\mathrm{cm})$ & & & & 0.258 & 0.612 & & 0.077 & 0.939 \\
\hline$\leq 3$ & $21(42.86 \%)$ & $9(47.37 \%)$ & $12(40.00 \%)$ & & & $33.30 \pm 25.60$ & & \\
\hline$>3$ & $28(57.14 \%)$ & $10(52.63 \%)$ & $18(60.00 \%)$ & & & $32.75 \pm 23.52$ & & \\
\hline Tumor location & & & & 0.587 & 0.746 & & 0.460 & 0.634 \\
\hline Cardia & $15(30.61 \%)$ & $7(36.84 \%)$ & $8(26.67 \%)$ & & & $32.48 \pm 19.10$ & & \\
\hline Body & $9(18.37 \%)$ & $3(15.80 \%)$ & $6(20.00 \%)$ & & & $34.69 \pm 31.86$ & & \\
\hline Antrum & $25(51.02 \%)$ & $9(47.36 \%)$ & $16(53.33 \%)$ & & & $27.03 \pm 22.25$ & & \\
\hline Differentiation & & & & 0.077 & 0.782 & & 1.008 & 0.319 \\
\hline Well and Moderate & $22(44.9 \%)$ & $9(47.37 \%)$ & $13(43.33 \%)$ & & & $33.82 \pm 24.47$ & & \\
\hline Low & $27(55.1 \%)$ & $10(52.63 \%)$ & $17(56.67 \%)$ & & & $27.08 \pm 22.25$ & & \\
\hline Borrmann-type & & & & 2.940 & 0.401 & & 0.583 & 0.659 \\
\hline I & $20(40.82 \%)$ & $10(52.63 \%)$ & $10(33.33 \%)$ & & & $32.46 \pm 24.38$ & & \\
\hline II & $23(46.94 \%)$ & $6(31.58 \%)$ & $17(56.67 \%)$ & & & $30.95 \pm 24.84$ & & \\
\hline III & $4(8.16 \%)$ & $2(10.53 \%)$ & $2(6.67 \%)$ & & & $20.80 \pm 8.57$ & & \\
\hline IV & $2(4.08 \%)$ & $1(5.26 \%)$ & $1(3.33 \%)$ & & & $15.50 \pm 1.56$ & & \\
\hline Pathological type & & & & 1.057 & 0.304 & & -1.284 & 0.206 \\
\hline Adenocarcinoma & $44(89.80 \%)$ & $16(84.21 \%)$ & $28(93.33 \%)$ & & & $28.68 \pm 23.35$ & & \\
\hline Other & $5(10.20 \%)$ & $3(15.79 \%)$ & $2(6.67 \%)$ & & & $42.68 \pm 20.35$ & & \\
\hline
\end{tabular}

ab187274) antibodies were used. The percentage of HLA-G positive cells was graded according to the following criteria:,$-<10 \% ;+, 10 \%-30 \% ;++, 30 \%-50 \% ;+++,>50 \%$ [36]. Five of 200 fields were randomly selected, and the mean value was used to account for the number of NK cells.

\section{Western blot}

Total protein was extracted after digesting the tissues and cells with lysis buffer. Equal amounts of protein were resolved via SDS-PAGE and transferred onto PVDF membranes. Then, the membranes were blocked with $5 \%$ non-fat dry milk in TBS for two hours, and incubated overnight at $4{ }^{\circ} \mathrm{C}$ with primary antibodies against the following proteins: HLA-G (1:500; Abcam, USA; catalog number: ab52455, clone: 4H84), ILT2 (1:1000; Abcam, USA; catalog number: ab170909), KIR2DL4 (1:1000; Abcam, USA; catalog number: ab107609), and GAPDH (1:1000; Abcam, USA; catalog number: ab9485). Next, the membranes were incubated with the secondary antibody for one hour, and specific protein bands on the membranes were detected using an enhanced chemiluminescence kit (Pierce Biotechnology, USA).

\section{Cell cultures}

Human GC cell lines MGC-803, BGC-823, MKN-28, MKN-45, SGC-7901 and AZ-521, human choriocarcinoma cell line JEG-3 (HLA-G positive control), human acute monocytic leukemia cell line THP-1 (ILT2 and KIR2DL4 positive control), and human NK cell line NK-92MI were purchased from the cell resources of the Shanghai Center for Life Science Research Institute of the Chinese Academy of Sciences. MGC-803, BGC-823, MKN-28, SGC-7901, AZ-521 and THP-1 cells were cultured in RPMI 1640 (Gibco, USA) medium supplemented with 10\% FBS (Gibco, USA). MKN-45 cells were cultured in RPMI 1640 (Gibco, USA) medium supplemented with 20\% FBS (Gibco, USA). JEG-3 cells were incubated in DMEM (Gibco, USA) medium with $10 \%$ FBS (Gibco, USA). NK-92 MI cells were incubated in MEM $\alpha$ (Gibco, USA) medium containing $12.5 \%$ FBS (Gibco, USA) and 12.5\% horse serum (Gibco, New Zealand). All these media were added with 1\% penicillin/ streptomycin (Gibco, USA). The culture flasks were placed in a humidified atmosphere containing 95\% air and $5 \% \mathrm{CO}_{2}$ at $37^{\circ} \mathrm{C}$.

\section{KARGER}




\section{Cellular Physiology Cell Physiol Biochem 2017;44:1828-1841 \\ \begin{tabular}{l|l|l}
\hline DOI: 10.1159/000485819 & $\begin{array}{l}\text { () } 2017 \text { The Author(s). Published by S. Karger AG, Basel } \\
\text { www.karger.com/cpb }\end{array}$ \\
\hline
\end{tabular}}

Table 2. Correlation of clinicopathologic feature with HLA-G expression and tumor-infiltrating NK cells (Part II)

\begin{tabular}{|c|c|c|c|c|c|c|c|c|}
\hline Clinicopathological feature & Total $(\mathrm{N}=49)$ & \multicolumn{2}{|c|}{ HLA-G expression } & \multirow{2}{*}{\multicolumn{3}{|c|}{$\begin{array}{c}\text { Infiltrating } \\
\text { NK cells } \\
\text { mean } \pm \text { SD }\end{array}$}} & $t / F$ & $p$ \\
\hline History of smoking & & & & & & & 0.894 & 0.376 \\
\hline Presence & $35(71.43 \%)$ & $15(78.95 \%)$ & $20(66.67 \%)$ & & & $28.22 \pm 21.50$ & & \\
\hline History of drinking & & & & 0.587 & 0.444 & & 0.413 & 0.681 \\
\hline Anemia & & & & 5.299 & $0.021^{*}$ & & -1.515 & 0.136 \\
\hline Absence & $26(53.06 \%)$ & $14(73.68 \%)$ & $12(40.00 \%)$ & & & $25.43 \pm 21.88$ & & \\
\hline Presence & $23(46.94 \%)$ & $5(26.32 \%)$ & $18(60.00 \%)$ & & & $35.39 \pm 24.14$ & & \\
\hline Hypoalbuminemia & & & & 0.291 & 0.590 & & 0.02 & 0.987 \\
\hline Absence & $26(53.06 \%)$ & $11(57.89 \%)$ & $15(50.00 \%)$ & & & $30.17 \pm 27.34$ & & \\
\hline Elevated & $9(18.37 \%)$ & $3(15.79 \%)$ & $6(20.00 \%)$ & & & $33.62 \pm 30.46$ & & \\
\hline CA19-9 & & & & 0.406 & 0.524 & & 0.722 & 0.474 \\
\hline Normal & $36(73.47 \%)$ & $13(68.42 \%)$ & $23(76.67 \%)$ & & & $31.56 \pm 22.66$ & & \\
\hline Elevated & $13(26.53 \%)$ & $6(31.58 \%)$ & $7(23.33 \%)$ & & & $26.09 \pm 25.38$ & & \\
\hline Invasion depth & & & & -2.502 & $0.012 *$ & & 2.525 & 0.091 \\
\hline $\mathrm{T} 1+\mathrm{T} 2$ & $8(16.33 \%)$ & $6(31.58 \%)$ & $2(6.67 \%)$ & & & $44.03 \pm 17.76$ & & \\
\hline $\mathrm{T} 3$ & $8(16.33 \%)$ & $4(21.05 \%)$ & $4(13.33 \%)$ & & & $35.90 \pm 18.54$ & & \\
\hline $\mathrm{T} 4$ & $33(67.34 \%)$ & $9(47.37 \%)$ & $24(80.00 \%)$ & & & $25.33 \pm 24.25$ & & \\
\hline Lymph Node Metastasis & & & & -2.443 & $0.015 *$ & & 17.212 & $<0.001^{*}$ \\
\hline No & $16(32.65 \%)$ & $11(57.89 \%)$ & $5(16.67 \%)$ & & & $53.19 \pm 24.35$ & & \\
\hline$* \mathrm{P}<0.01$ & & & & & & & & \\
\hline
\end{tabular}

\section{Cell transfection}

TheHLA-G(LV5-HLA-G),ILT2 (LV5-ILT2) and non-targeted negative controlviruses(LV5) werepurchased fromShanghaiGenePharmaCo.Ltd.(China).Lentivectorswerepreparedusing293Tcells.Cellsweretransfected with lentiviral plasmids and accessory plasmids (LV5, PG-P1-VSVG, PG-P2-REV, and PG-P3-RRE). MGC-803 cells were transduced with LV5-HLA-G to overexpress HLA-G. NK-92MI cells were transduced with LV5-ILT2 to overexpress ILT2. Moreover, empty lentiviral vectors were added to the control cells. The HLA-G sequence was: forward, 5'-GCGGCCGCTCCCCAGAC-3'; reverse, 5'-GGATCCCCTTTTCAATCTGAGCTCTTCTTTC-3'. The ILT2 sequence was: forward, 5'-GCGGCCGCGCCACCATGACCCCCATCCTCACGGTCCTGAT-3'; reverse, 5'-ATGCATCTAGTGGATGGCCAGAGTGGCGTA-3'.

\section{Cell isolation and flow cytometry}

Tumor-infiltrating lymphocytes were obtained from tissue samples, as previously described [37]. The lymphocytes were washed and resuspended in medium supplemented with 1\% FBS for flow cytometry. CD3-PE-CF594 and CD56-BV421 were purchased from BD Bioscience. ILT2-PE and KIR2DL4-PE were purchased from R\&D System. Flow cytometry (BD Influx, BD Biosciences) was used to detect the expression of surface receptors ILT2 and KIR2DL2 in NK cells (CD3 ${ }^{-} \mathrm{CD}^{-} 6^{+}$). Flow cytometric analysis was carried out using FlowJo 10.2 software (FLOWJO, USA).

\section{Quantitative RT-PCR}

Total RNA from cells was isolated using TRIzol (TaKaRa, Dalian, China). The concentration and purity of the total RNA samples were measured using a UV spectrophotometer (UltroSPec2100 Pro, Amersham, USA). Total RNA was reverse-transcribed using a PrimeScript RT Reagent kit (TaKaRa, Dalian, China). 


\section{Cellular Physiology Cell Physiol Biochem 2017;44:1828-1841 \begin{tabular}{l|l} 
and Biochemistry Published online: November 07, 2017 & $\begin{array}{l}\text { (c) } 2017 \text { The Author(s). Published by S. Karger AG, Basel } \\
\text { www.karger.com/cpb }\end{array}$
\end{tabular} \\ Wan et al.: Human Leukocyte Antigen-G Inhibits Natural Killer Cells}

The primers for HLA-G and $\beta$-actin were as follows: HLA-G (forward 5'-GAGGAGACACGGAACACCAAG-3', reverse 5'-GGTCGCAGCCAATCATCC-3'); $\beta$-actin (forward 5'-TGACGTGGACATCCGCAAAG-3', reverse 5'-CTGGAAGGTGGACAGCGAGG-3'). Quantitative RT-PCR was performed using the CFX96 ${ }^{\text {TM }}$ Real-Time System (Bio-Rad, USA) and SYBR Premix Ex Taq ${ }^{\text {TMII }}$ (TaKaRa, Dalian, China). Mean relative gene expression was determined using the $2^{-\Delta \Delta C T}$ method.

\section{Cell proliferation detection}

Co-culture proliferation assays were performed using NK-92MI cells (ILT2 overexpression or low expression) (2, 000 cells/well) and $\gamma$-irradiated (40 Gy) MGC-803 cells (HLA-G overexpression or low expression) (1, 000 cells/well). In addition, antibody 5A6G7 (Abcam, USA; catalog number: ab76869) (10 $\mu \mathrm{g} / \mathrm{ml}$ ) blocking HLA-G was used. Cell proliferation was examined at 1, 2, 3, 4, 5, 6 and 7 days post-radiation using Cell Counting Kit-8 (CCK8; Dojindo, Japan), according to manufacturer's instructions.

\section{Cell-mediated cytotoxic activity assay}

Cytotoxic activity assay was performed using NK-92MI cells (ILT2 overexpression or low expression) as effector cells. MGC-803 cells (HLA-G overexpression or low expression) were used as target cells. The effector-to-target cell ratio (E:T) was 2.5:1, 5:1, 10:1 and 20:1, respectively. In addition, antibody 5A6G7 (Abcam, USA; catalog number: ab76869) $(10 \mu \mathrm{g} / \mathrm{ml})$ blocking HLA-G was used. A colorimetric-based LDH assay (CytoTox $96{ }^{\circledR}$ non-radioactive cytotoxic activity assay; Promega, USA) was used, and the cytotoxic activity was calculated according to manufacturer's instructions. The percentage of specific lysis was calculated using the formula: [(test release - spontaneous release) / (maximum release - spontaneous release)] $\times 100$.

\section{ELISA}

The co-culture supernatant concentrations of IFN- $\gamma$ and TNF- $\alpha$ (Abcam, USA) were determined using ELISA kits at 0,12, 24, 48 and 72 hours post-radiation, according to manufacturer's instructions.

\section{In vivo experiments}

A mouse xenograft model was established using 6-8-week-old male non-obese, severe combined immunodeficient/beige (NOD/SCID) mice, which were obtained from the Laboratory Animal Center of Chongqing Medical University. MGC-803 cells (HLA-G overexpression or low expression) $\left(2 \times 10^{6}\right)$ were subcutaneously injected into the right flank of each mouse. Two weeks later, mice were given an intravenous injection of $1 \times 10^{7}$ of either NK-92MI (ILT2 overexpression) or NK-92MI (ILT2 low expression) cells. PBS (100 $\mu \mathrm{l})$ was used for the control group. Tumor volumes were calculated using the following formula: $\mathrm{V}\left(\mathrm{mm}^{3}\right)=$ length $\times$ width $\times$ width $/ 2$. All animal protocols were conducted in accordance with the Institutional Animal Ethics Care and Use Committee of the First Affiliated Hospital of Chongqing Medical University.

\section{Statistical analysis}

Statistical analysis was performed using SPSS 22.0 software (IBM, USA). Continuous data were expressed as mean \pm standard deviation (SD). Categorical data were expressed as frequency or percentage. Student's $t$-test or ANOVA was used to compare continuous data. The Mann-Whitney U-test was used for continuous variables that did not conform to the normal distribution (by Shapiro-Wilk test) or categorical data. The chi-square test was used to analyze categorical data. The correlation analysis was performed by Spearman's $\rho$ coefficients. Survival curves were calculated using the Kaplan-Meier method, and compared using the Log-rank test. Cox regression analysis was carried out to identify the independent prognostic factors for predicting survival. $P<0.05$ was considered statistically significant.

\section{Results}

Relationship between elevated HLA-G expression and clinical significance indicated a poor prognosis for gastric cancer

Immunohistochemistry data revealed that the overall positive rate of the expression of HLA-G in cancer tissue was $61.22 \%$ (30/49), including a weak positive rate of $8.16 \%$ 


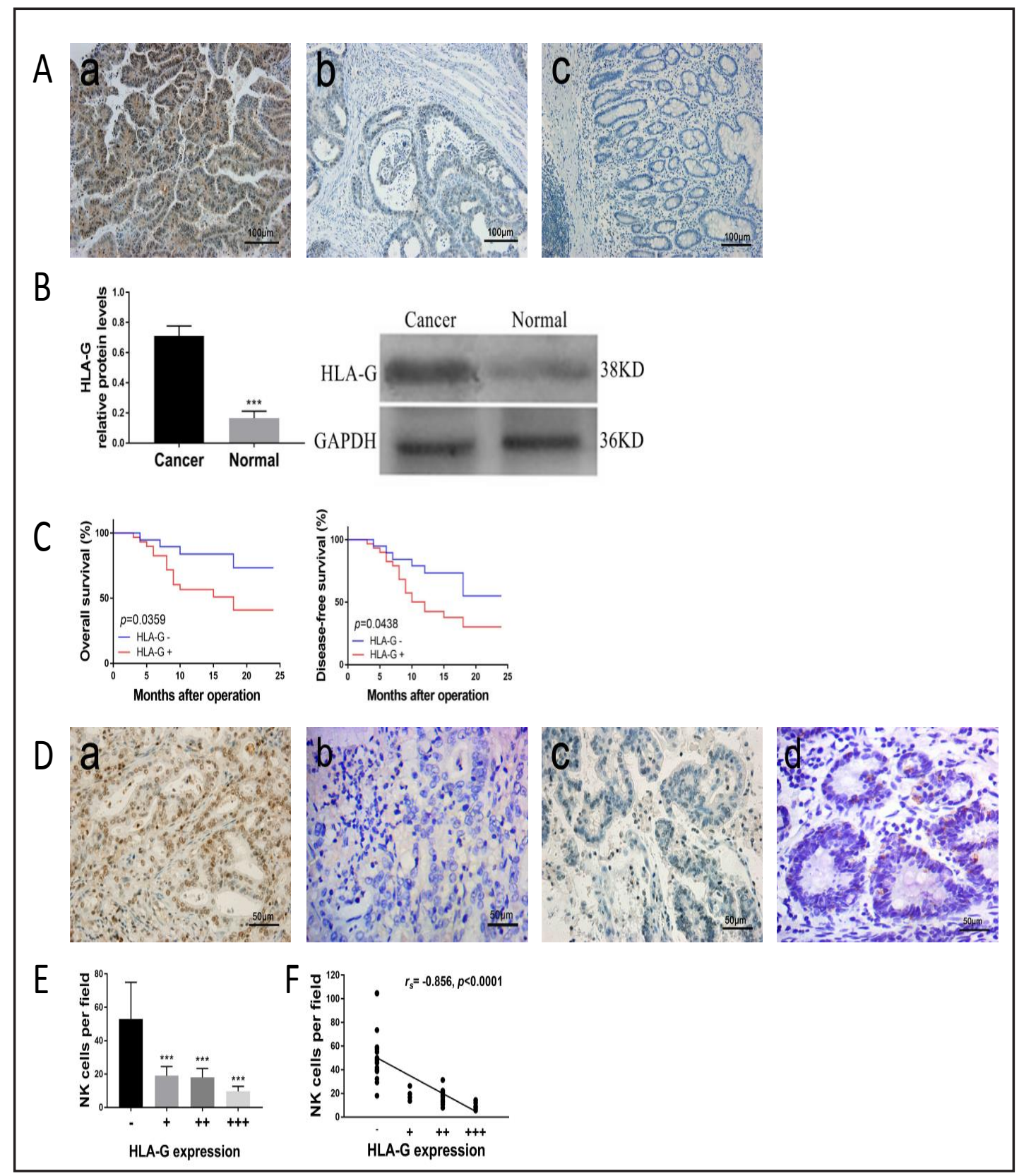

Fig. 1. HLA-G expression in gastric cancer and the correlations between HLA-G expression and tumorinfiltrating NK cells. (A) Immunohistochemical staining of HLA-G (200x): a, positive expression in cancer tissues; b, negative expression in cancer tissues; c, negative expression in normal tissue. (B) Westernblot analysis of HLA-G expression in gastric cancer tissues was significantly higher compared to normal tissues $\left({ }^{* * *} \mathrm{P}<0.001\right)$. (C) Cumulative 2-years OS and DFS curves of the patients positive or negative for HLA-G expression. (D) Immunohistochemical staining of HLA-G and CD57 respectively in gastric cancer tissues (400x): a, HLA-G positive; b, CD57 low density; c, HLA-G negative; d, CD57 high density. (E) Statistical analysis of the number of tumor-infiltrating NK cells with different levels of HLA-G expression $\left({ }^{* * *} \mathrm{P}<0.001\right.$ vs. HLA-G negative). (F) The negative correlation with the density of NK cells and HLA-G expression.

(4/49), a median positive rate of $36.69 \%$ (17/49), and a strong positive rate of $18.37 \%$ (9/49). However, no expression was observed in normal tumor-adjacent tissues (Fig. 1A). In addition, western blot data revealed that the expression of HLA-G in cancer tissue was

\section{KARGER}




\section{Cellular Physiology Cell Physiol Biochem 2017;44:1828-1841 \begin{tabular}{l|l} 
and Biochemistry Published online: November 07, 2017 & $\begin{array}{l}\text { (c) } 2017 \text { The Author(s). Published by S. Karger AG, Basel } \\
\text { www.karger.com/cpb }\end{array}$
\end{tabular} \\ Wan et al.: Human Leukocyte Antigen-G Inhibits Natural Killer Cells}

Table 3. Univariate and Multivariate analysis of prognostic variables

\begin{tabular}{lcccccc}
\hline \multirow{2}{*}{ Variables } & \multicolumn{3}{c}{ Univariate analysis } & \multicolumn{3}{c}{ Multivariate analysis } \\
& $\mathrm{p}(\mathrm{OS})$ & $\mathrm{p}$ (DFS) & $\mathrm{p}$ (OS) & $95 \%$ CI & $\mathrm{p}$ (DFS) & $95 \%$ CI \\
\hline Gender & 0.678 & 0.513 & $\mathrm{NA}$ & $\mathrm{NA}$ & $\mathrm{NA}$ & $\mathrm{NA}$ \\
Age & 0.862 & 0.718 & $\mathrm{NA}$ & $\mathrm{NA}$ & $\mathrm{NA}$ & $\mathrm{NA}$ \\
Tumor size & 0.557 & 0.352 & $\mathrm{NA}$ & $\mathrm{NA}$ & $\mathrm{NA}$ & $\mathrm{NA}$ \\
Differentiation & 0.879 & 0.377 & $\mathrm{NA}$ & $\mathrm{NA}$ & $\mathrm{NA}$ & $\mathrm{NA}$ \\
Pathological type & 0.974 & 0.587 & $\mathrm{NA}$ & $\mathrm{NA}$ & $\mathrm{NA}$ & $\mathrm{NA}$ \\
History of smoking & 0.703 & 0.807 & $\mathrm{NA}$ & $\mathrm{NA}$ & $\mathrm{NA}$ & $\mathrm{NA}$ \\
History of drinking & 0.486 & 0.392 & $\mathrm{NA}$ & $\mathrm{NA}$ & $\mathrm{NA}$ & $\mathrm{NA}$ \\
Anemia & 0.896 & 0.863 & $\mathrm{NA}$ & $\mathrm{NA}$ & $\mathrm{NA}$ & $\mathrm{NA}$ \\
Hypoalbuminemia & 0.544 & 0.666 & $\mathrm{NA}$ & $\mathrm{NA}$ & $\mathrm{NA}$ & $\mathrm{NA}$ \\
CEA & 0.498 & 0.551 & $\mathrm{NA}$ & $\mathrm{NA}$ & $\mathrm{NA}$ & $\mathrm{NA}$ \\
CA19-9 & 0.975 & 0.617 & $\mathrm{NA}$ & $\mathrm{NA}$ & $\mathrm{NA}$ & $\mathrm{NA}$ \\
Invasion depth & 0.261 & 0.197 & 0.322 & $0.436-12.479$ & 0.238 & $0.581-8.917$ \\
Lymph node metastasis & 0.390 & 0.270 & 0.755 & $0.308-2.350$ & 0.917 & $0.395-2.300$ \\
AJCC stage & 0.084 & 0.093 & 0.147 & $0.654-17.194$ & 0.153 & $0.719-8.198$ \\
HLA-G expression & 0.050 & 0.057 & 0.356 & $0.500-6.886$ & 0.412 & $0.549-4.307$ \\
CI, confidence interval; NA, not assessed & & & & & &
\end{tabular}

significantly higher when compared to normal tumor-adjacent tissues $(P<0.001$, Fig. 1B). By comparing the clinical characteristics of GC patients with different HLA-G expression, it was found that the expression of HLA-G was significantly correlated with preoperative anemia $(P=0.021)$, tumor invasion depth $(P=0.012)$, lymph node metastasis $(P=0.015)$ and clinical stages $(P=0.001)$; but not with other clinical characteristics (Table 1 and Table 2). The survival analysis demonstrated that the 2-year overall survival (OS) and disease-free survival (DFS) rate in patients with positive HLA-G expression was significantly lower compared to patients with negative HLA-G expression $(P=0.036$ and $P=0.044$, Fig. $1 C)$. Subsequently, the Cox regression multivariate analysis revealed that HLA-G expression was not significant in terms of the independent prognostic factors for OS and DFS (Table 3).

The decrease in tumor-infiltrating NK cells is associated with the expression of HLA-G and involved in tumor development

Infiltrating NK cells in GC tissue were detected by immunohistochemistry. Compared with HLA-G expression results, the result in this study revealed that the number of infiltrating NK cells in the HLA-G positive group was significantly lower compared to that in the HLA-G negative group $(P<0.001)$, but no statistical significance was observed among these three HLA-G positive groups $(P=0.999, P=0.762$ and $P=0.591$; Figs. $1 \mathrm{D}$ and $1 \mathrm{E})$. The correlation between the expression of HLA-G and infiltrating NK cells indicate a significant negative correlation $(P<0.001$, Fig. 1F). Meanwhile, by comparing the number of infiltrating NK cells in each clinical characteristic group of GC patients, it was found that there was a statistical significance between the lymph node metastasis group $(P<0.001)$ and clinical staging group $(P=0.008)$; but no statistical significance was observed when compared with the other groups (Table 1 and Table 2).

HLA-G expression in gastric cancer cell lines and transfection in the MGC-803 cell line

Western blot and qPCR data demonstrated that HLA-G expression in MGC-803, BGC-823, MKN-28, MKN-45, SGC-7901 and AZ-521 cell lines were lower compared to positive control cell line JEG-3 $(P<0.001)$. However, no statistical significance was observed in various GC cell lines (Fig. 2A). Then, lentivirus was used to transfect the MGC-803 cell line to overexpress HLA-G. Western blot detection revealed that the expression of HLA-G in transfected MGC-803 cells was higher when compared to the control groups (blank and empty plasmid) $(P<0.001$, Fig. 2B) 


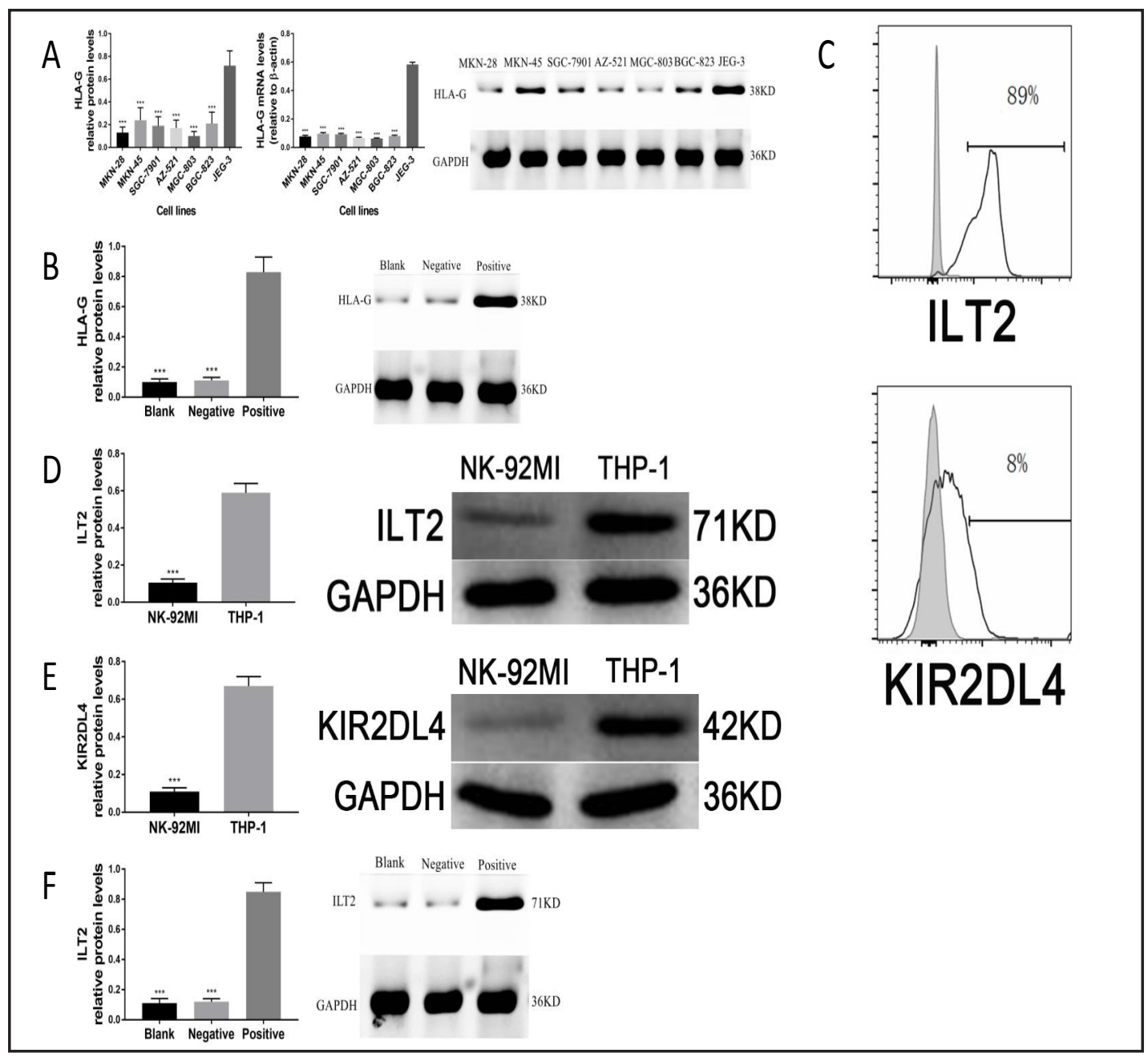

Fig. 2. HLA-G expression in gastric cancer cell lines, phenotype of tumor-infiltrating NK cells and the receptor expression in NK-92MI cells. (A) HLA-G expression in various gastric cancer lines was lower compared to positive control cell line JEG-3 by western-blot and qPCR ( ${ }^{* *} \mathrm{P}<0.001$ vs. positive control). (B) Western-blot analysis of HLA-G expression after transfection ( ${ }^{* * *} \mathrm{P}<0.001$ vs. positive): Blank, MGC-803 alone; Negative, MGC-803 transfected with empty vector; Positive, MGC-803 transfected with HLA-G. (C) The percentage of tumor-infiltrating NK cells expressing ILT2 is higher compared to tumor-infiltrating NK cells expressing KIR2DL4 by flow cytometry assessment. (D, E) Expression of HLA-G receptors on NK-92MI cells analyzed by western-blot $\left({ }^{* * *} \mathrm{P}<0.001\right.$ vs. THP-1). (F) Western-blot analysis of ILT2 expression after transfection $\left({ }^{* *} \mathrm{P}<0.001\right.$ vs. positive): Blank, NK-92MI alone; Negative, NK-92MI transfected with empty vector; Positive, NK-92MI transfected with ILT2.

The expression of receptors ILT2 and KIR2DL4 in tumor-infiltrating NK cells in gastric cancer patients and its transfection in the NK-92MI cell line

Flow cytometry was used to detect HLA-G inhibitory receptor ILT2 and KIR2DL4 on the surface of infiltrating NK cells in GC tissues. The results of the present study revealed that the positive rate of ILT2 on the cell surface was $89 \%$, while the positive rate of KIR2DL4 was 8\% (Fig. 2C). However, western blot results revealed that the expression of ILT2 and KIR2DL4 in the NK-92MI cell line was lower when compared to positive control cell line THP-1 $(P<0.001$, Figs. 2D and 2E). In order to detect the function of ILT2 in NK cells, lentivirus was transfected into the NK-92MI cell line to overexpress ILT2. The expression of ILT2 in NK-92MI cells was higher compared to the control groups (blank and empty plasmid) after transfection $(P<0.001$, Fig. 2F). 


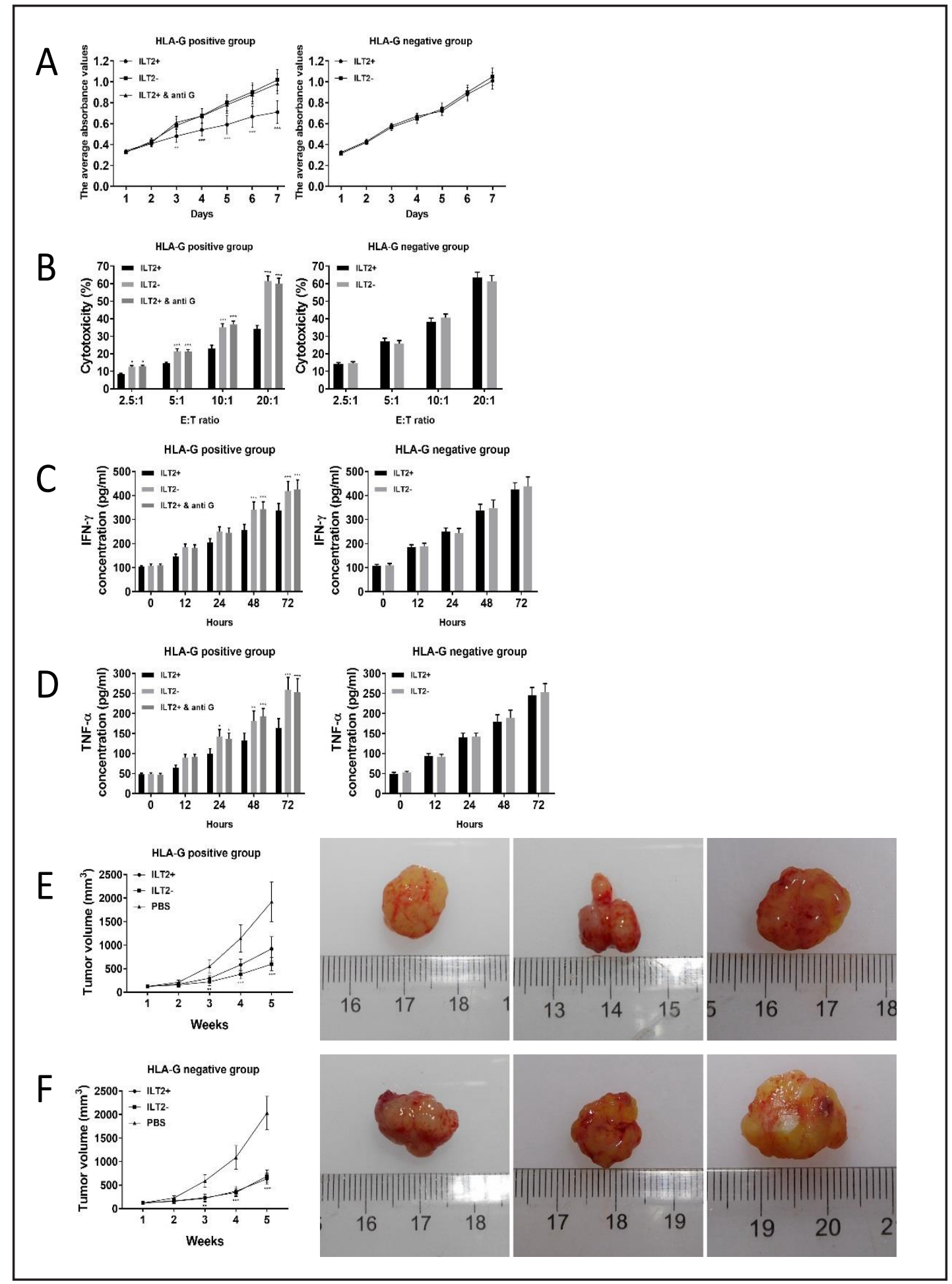

Fig. 3. HLA-G suppresses NK cell proliferation, cytotoxic activity and cytokine production in vitro and suppresses the anti-tumor effect of NK cells in vivo via ILT2 receptor. (A) Cell proliferation was measured by CCK8 assays (** $\mathrm{P}<0.01$, $\left.{ }^{* * *} \mathrm{P}<0.001\right)$. (B) Cell cytotoxic activity was measured by lactate dehydrogenase (LDH)-release method $\left({ }^{*} \mathrm{P}<0.05,{ }^{* * *} \mathrm{P}<0.001\right)$. (C, D) Concentration of IFN- $\gamma$ and TNF- $\alpha$ were measured by ELISA kits $\left({ }^{*} \mathrm{P}<0.05,{ }^{* *} \mathrm{P}<0.01,{ }^{* * *} \mathrm{P}<0.001\right)$. (E, F) Tumor volume after NK cells injection in cancer xenograft model $\left({ }^{* *} \mathrm{P}<0.01,{ }^{* * *} \mathrm{P}<0.001\right)$. ILT2+, NK-92MI cell of overexpress ILT2; ILT2-, NK-92MI cell of low express ILT2; ILT2+ \& anti G, NK-92 MI cell of overexpress ILT2 plus HLA-G antibody; PBS, negative control.

\section{KARGER}




\section{Cellular Physiology Cell Physiol Biochem 2017;44:1828-1841 \begin{tabular}{l|l|l} 
and Biochemistry Published online: November 07, 2017 & $\begin{array}{l}\text { (c) } 2017 \text { The Author(s). Published by S. Karger AG, Basel } \\
\text { www.karger.com/cpb }\end{array}$
\end{tabular} \\ Wan et al.: Human Leukocyte Antigen-G Inhibits Natural Killer Cells}

HLA-G suppresses NK cell proliferation, cytotoxic activity and cytokine production via ILT2

These results show that with overexpression of HLA-G in the GC cell group, the proliferation rate, cytotoxic activity and cytokine production of NK cells with ILT2 overexpression were significantly lower than those of NK cells with low ILT2 expression. In the subgroup plus HLA-G antibody, the proliferation rate, cytotoxic activity and cytokine production of NK cells with overexpressed ILT2 were recovered $(P<0.05)$. In addition, in the GC cell group with HLA-G low expression, the difference in effect in each NK cell subgroup was not statistically significant (Figs. 3A, 3B, 3C and 3D).

\section{HLA-G suppresses the anti-tumor effect of NK cells in vivo}

The results of the cancer xenograft model revealed the size of tumors in the GC cell group with overexpressed HLA-G, which were as follows: small, in the subgroup injected with NK cells with low ILT2 expression $(P<0.01)$; medium, in the subgroup injected with NK cells with overexpressed ILT2 $(P<0.01)$; large, in the control subgroup (Fig. 3E). There was no significant difference in tumor size observed in the GC cell group with low HLA-G expression, when compared with the NK cell subgroup. In addition, both groups had significantly smaller tumor sizes, compared to the control subgroup $(P<0.01$, Fig. 3 F $)$.

\section{Discussion}

In the present study, our results suggest that the expression of HLA-G was negatively correlated with the number of tumor-infiltrating NK cells in GC tissues for the first time. Our in vitro experiments demonstrate and confirm that HLA-G can inhibit NK cell proliferation and cytotoxic activity by binding with the ILT2 receptor, and reduce the production of IFN- $\gamma$ and TNF- $\alpha$. In addition, by using a mice animal model bearing a GC xenograft, we were able to prove that HLA-G can inhibit the anti-tumor effect of NK cells via the ILT2 receptor.

HLA-G plays an important role in tumor immune escape, and is an important immunosuppressive molecule. It was found that HLA-G is expressed in gastrointestinal tumors, and is closely correlated to poor cancer prognosis $[38,39]$. In the present study, we observed that HLA-G was expressed in most GC tissues, and were closely correlated with the depth of tumor invasion, lymph node metastasis and clinical staging; which were consequently involved in GC development [40-42]. Moreover, several other studies have shown that HLA-G may be involved in the development of liver cancer, ovarian cancer and breast cancer [43-46]. In addition, we also found that the proportion of pre-operative anemia patients with HLA-G positive expression was higher compared to patients with HLA-G negative expression. Since pre-operative anemia was associated with tumor cachexia, this might suggest that HLA-G expression was closely related to the adverse prognosis of tumors. Furthermore, the OS and DFS data were similar to the results published in previous studies [40-42]. We also found that HLA-G expression was negatively correlated with the number of tumor-infiltrating NK cells in GC tissues for the first time, suggesting that HLA-G may inhibit the proliferation of NK cells. We further compared the number of infiltrating NK cells with different clinical characteristics, and confirmed that the reduction in tumor-infiltrating NK cells was associated with the poor prognosis of the tumor $[10,11,13,47]$. In addition, in our initial hypothesis, we confirmed that HLA-G may inhibit the function of infiltrating NK cells to promote the development of GC.

HLA-G is considered as an important factor in inhibiting NK cell function [48-50]. At present, there are two types of HLA-G inhibitory receptors associated with NK cells: immunoglobulin-like transcripts 2, ILT2 (CD85j/LILRB1); killer cell immunoglobulin-like receptors 2DL4, KIR2DL4 (CD158d). ILT2 is mainly expressed in monocytes, macrophages, dendritic cells, B cells, and in some T cells and NK cells; while KIR2DL4 is mainly expressed in uterine NK cells $[50,51]$. The intracellular domain of ILT2 contains four immunoreceptor tyrosine-type inhibition motifs (ITIMs), which can transmit inhibitory signals into cells and inhibit the activity of immune cells. Moreover, the affinity of ILT2 and HLA-G is significantly higher compared to KIR2DL4 [52,53]. The intracellular fraction of KIR2DL4 contains only 


\section{Cellular Physiology Cell Physiol Biochem 2017;44:1828-1841

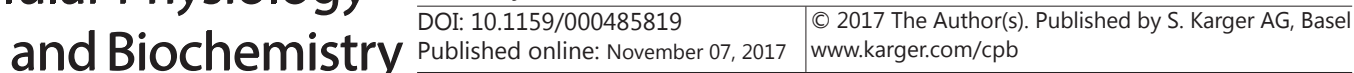 \\ Wan et al.: Human Leukocyte Antigen-G Inhibits Natural Killer Cells}

one ITIM, but it also has an arginine residue that interacts with FceRI $\gamma$, allowing it to possess both the inhibitory and structural features of the activated receptor, thereby making cell regulation more complex [54-56].

In order to further study the mechanism of HLA-G on NK cells, we identified the expression of HLA-G in six GC cell lines. We found that HLA-G was lower in all cell lines, which was consistent with previous studies [40]. Previous researches have demonstrated that HLA-G expression in ovarian cancer and melanoma decreased or even completely disappeared after long-term culture of fresh HLA-G positive tumor cells in vitro [57-60], suggesting that the expression of HLA-G in tumor cells is regulated by the tumor microenvironment [61]. In addition, by using flow cytometry, we found that tumor-infiltrating NK cells were mainly expressed in ILT2. Furthermore, western blot data revealed that ILT2 and KIR2DL4 were low in NK-92MI cells [62]. In order to simulate these in vivo conditions, we used lentivirus to transfect NK-92MI cells to overexpress ILT2, and the lentivirus transfection of MGC-803 cells to overexpress HLA-G. The results of the cell proliferation and cytotoxic activity suggest that HLA-G can inhibit the function of NK cells through ILT2 receptors, and the inhibitory role of HLA-G can be blocked by the HLA-G antibody, which was consistent with studies that investigated lymphoma and liver cancer $[63,64]$. Similarly, we also observed that the overexpression of HLA-G can reduce the production of IFN- $\gamma$ and TNF- $\alpha$ via ILT2, and that its role can also be blocked by the HLA-G antibody. TNF- $\alpha$ is important in inhibiting tumor growth in most tumors [65]. IFN- $\gamma$ is mainly secreted by NK cells, which is relevant for inhibiting tumor growth in non-inflammatory-induced tumors [66]. Consequently, the reduction of cytokines with tumor killing may represent another mechanism by which HLA-G can exert its immunosuppression.

During the animal experiments, NOD/SCID mice with extremely low activity of self NK cells were used to establish a cancer xenograft model in vivo. We made this choice, because NOD/SCID mice have very low NK cell activity compared to nude mice, which is the ideal animal model for this kind of experiment. Briefly, our results revealed that in the GC group with overexpressed HLA-G, NK cells with low expression of ILT2 revealed an anti-tumor effect; and tumor size was significantly smaller compared to the control group. In addition, the anti-tumor effect of NK cells with high expression of ILT2 was partially inhibited, and the tumor size increased; but this was still smaller compared to the control group. Although, these in vitro experiments revealed that HLA-G could inhibit the function of NK cells by ILT2, the in vivo experiments revealed that $\mathrm{NK}$ cell function remained partially retained. The reason might be that these NK cells were also subjected to the regulation of complex environmental factors in vivo, and affected by other immune cells in mice. On the contrary, in the GC group with low HLA-G expression, NK cells exhibited an anti-tumor activity, regardless of the expression level of ILT2. This further suggests that HLA-G can inhibit the anti-tumor effect of NK cells by ILT2.

\section{Conclusion}

HLA-G plays an important role in the development, progression and adverse prognosis of GC; and its mechanism may be that it inhibits the function of infiltrating NK cells in GC. Our data demonstrates and re-confirms that HLA-G inhibits NK cell proliferation and cytotoxic activity through ILT2. Recent studies have considered HLA-G/ILT was an important immunological target, and that this is as important as B7/CTLA-4 and PD-L1/PD-1 in tumor immunotherapy [51,67]. This study provides a theoretical basis for the participation of HLA-G in the immune escape of GC, and provides a new strategy for the immunotherapy of GC using HLA-G as the main target. However, further studies are required to clarify the specific molecular mechanism underlying the role of HLA-G in GC.

\section{Disclosure Statement}

The authors declare that they have no competing interests. 


\section{Cellular Physiology Cell Physiol Biochem 2017;44:1828-1841 \begin{tabular}{l|l|l|}
\hline DOI: 10.1159/000485819 & 2017 The Author(s). Published by S. Karger AG, Basel \\
\hline
\end{tabular} Published online: November 07, 2017 www.karger.com/cpb}

\section{Acknowledgements}

This work was supported by the National Natural Science Foundation of China (No.81272753) and National Key Clinical Specialties Construction Program of China(No [2012].649).

\section{References}

1 McLean MH, El-Omar EM: Genetics of gastric cancer. Nat Rev Gastroenterol Hepatol 2014;11:664-674.

$\checkmark 2$ Chen WQ, Zheng RS, Baade PD, Zhang SW, Zeng HM, Bray F, Jemal A, Yu XQ, He J: Cancer Statistics in China, 2015. CA Cancer J Clin 2016;66:115-132.

3 Mellman I, Coukos G, Dranoff G: Cancer immunotherapy comes of age. Nature 2011;480:480-489.

4 Mantovani A, Romero P, Palucka AK, Marincola FM: Tumour immunity: effector response to tumour and role of the microenvironment. Lancet 2008;371:771-783.

5 Vesely MD, Kershaw MH, Schreiber RD, Smyth MJ: Natural innate and adaptive immunity to cancer. Annu Rev Immunol 2011;29:235-271.

6 Smyth MJ, Crowe NY, Godfrey DI: NK cells and NKT cells collaborate in host protection from methylcholanthrene-induced fibrosarcoma. Int Immunol 2001;13:459-463.

7 Tang X, Huang J, Xiong H, Zhang K, Chen C, Wei X, Xu X, Xie Q, Huang R: Anti-Tumor Effects of the Polysaccharide Isolated from Tarphochlamys Affinis in H22 Tumor-Bearing Mice. Cell Physiol Biochem 2016;39:1040-1050.

8 Zhu Y, Lai X, Zhao S, Zheng J, Wang X, Weng X, Li J, Ye Y, Chen Q, Lin X: Antitumor enhancement by irradiated haploidentical donor lymphocyte infusion of mice with melanoma. Cell Physiol Biochem 2015;35:21812191.

-9 Wu Y, Kuang DM, Pan WD, Wan YL, Lao XM, Wang D, Li XF, Zheng L: Monocyte/macrophage-elicited natural killer cell dysfunction in hepatocellular carcinoma is mediated by CD48/2B4 interactions. Hepatology 2013;57:1107-1116.

10 Coca S, Perez-Piqueras J, Martinez D, Colmenarejo A, Saez MA, Vallejo C, Martos JA, Moreno M: The prognostic significance of intratumoral natural killer cells in patients with colorectal carcinoma. Cancer 1997;79:2320-2328.

11 Li T, Zhang Q Jiang Y, Yu J, Hu Y, Mou T, Chen G, Li G: Gastric cancer cells inhibit natural killer cell proliferation and induce apoptosis via prostaglandin E2. Oncoimmunology 2015;5:e1069936.

-12 Izawa S, Kono K, Mimura K, Kawaguchi Y, Watanabe M, Maruyama T, Fujii $\mathrm{H}_{2} \mathrm{H}_{2} \mathrm{O}_{2}$ production within tumor microenvironment inversely correlated with infiltration of CD56(dim) NK cells in gastric and esophageal cancer: possible mechanisms of NK cell dysfunction. Cancer Immunol Immunother 2011;60:1801-1810.

13 Ishigami S, Natsugoe S, Tokuda K, Nakajo A, Che X, Iwashige H, Aridome K, Hokita S, Aikou T: Prognostic value of intratumoral natural killer cells in gastric carcinoma. Cancer 2000;88:577-583.

14 Geraghty DE, Koller BH, Orr HT: A human major histocompatibility complex class I gene that encodes a protein with a shortened cytoplasmic segment. Proc Natl Acad Sci U S A 1987;84:9145-9149.

15 Kovats S, Main EK, Librach C, Stubblebine M, Fisher SJ, DeMars R: A class I antigen, HLA-G, expressed in human trophoblasts. Science 1990;248:220-223.

-16 Le Discorde M, Moreau P, Sabatier P, Legeais JM, Carosella ED: Expression of HLA-G in human cornea, an immune-privileged tissue. Human Immunol 2003;64:1039-1044.

$>17$ Ito T, Ito N, Saathoff M, Stampachiacchiere B, Bettermann A, Bulfone-Paus S, Takigawa M, Nickoloff BJ, Paus $\mathrm{R}$ : Immunology of the human nail apparatus: the nail matrix is a site of relative immune privilege. J Invest Dermatol 2005;125:1139-1148.

18 Crisa L, McMaster MT, Ishii JK, Fisher SJ, Salomon DR: Identification of a thymic epithelial cell subset sharing expression of the class Ib HLA-G molecule with fetal trophoblasts. J Exp Med 1997;186:289-298.

19 Cirulli V, Zalatan J, McMaster M, Prinsen R, Salomon DR, Ricordi C, Torbett BE, Meda P, Crisa L: The class I HLA repertoire of pancreatic islets comprises the nonclassical class Ib antigen HLA-G. Diabetes 2006;55:1214-1222.

20 Menier C, Rabreau M, Challier JC, Le Discorde M, Carosella ED, Rouas-Freiss N: Erythroblasts secrete the nonclassical HLA-G molecule from primitive to definitive hematopoiesis. Blood 2004;104:3153-3160. 


\section{Cellular Physiology Cell Physiol Biochem 2017;44:1828-1841 \begin{tabular}{l|l} 
and Biochemistry Published online: November 07, 2017 & $\begin{array}{l}\text { (c) } 2017 \text { The Author(s). Published by S. Karger AG, Basel } \\
\text { www.karger.com/cpb }\end{array}$
\end{tabular}}

Wan et al.: Human Leukocyte Antigen-G Inhibits Natural Killer Cells

21 Selmani Z, Naji A, Zidi I, Favier B, Gaiffe E, Obert L, Borg C, Saas P, Tiberghien P, Rouas-Freiss N, Carosella ED, Deschaseaux F: Human leukocyte antigen-G5 secretion by human mesenchymal stem cells is required to suppress T lymphocyte and natural killer function and to induce CD4+CD25highFOXP3+ regulatory T cells. Stem cells 2008;26:212-222.

-22 Rouas-Freiss N, Moreau P, Ferrone S, Carosella ED: HLA-G proteins in cancer: do they provide tumor cells with an escape mechanism? Cancer Res 2005;65:10139-10144.

-23 Aractingi S, Briand N, Le Danff C, Viguier M, Bachelez H, Michel L, Dubertret L, Carosella ED: HLA-G and NK receptor are expressed in psoriatic skin: a possible pathway for regulating infiltrating T cells? Am J Pathol 2001;159:71-77.

24 Lafon M, Prehaud C, Megret F, Lafage M, Mouillot G, Roa M, Moreau P, Rouas-Freiss N, Carosella ED: Modulation of HLA-G expression in human neural cells after neurotropic viral infections. J Virol 2005;79:15226-15237.

25 Khosrotehrani K, Le Danff C, Reynaud-Mendel B, Dubertret L, Carosella ED, Aractingi S: HLA-G expression in atopic dermatitis. J Invest Dermatol 2001;117:750-752.

26 Gonzalez A, Rebmann V, LeMaoult J, Horn PA, Carosella ED, Alegre E: The immunosuppressive molecule HLA-G and its clinical implications. Crit Rev Clin Lab Sci 2012;49:63-84.

27 Dahl M, Hviid TV: Human leucocyte antigen class Ib molecules in pregnancy success and early pregnancy loss. Hum Reprod Update 2012;18:92-109.

28 Hsu P, Nanan RK: Innate and adaptive immune interactions at the fetal-maternal interface in healthy human pregnancy and pre-eclampsia. Front Immunol 2014;5:125.

29 Deschaseaux F, Delgado D, Pistoia V, Giuliani M, Morandi F, Durrbach A: HLA-G in organ transplantation: towards clinical applications. Cell Mol Life Sci 2011;68:397-404.

-30 Yan WH: Human leukocyte antigen-G in cancer: are they clinically relevant? Cancer Lett 2011;311:123-130.

-31 Fuzzi B, Rizzo R, Criscuoli L, Noci I, Melchiorri L, Scarselli B, Bencini E, Menicucci A, Baricordi OR: HLA-G expression in early embryos is a fundamental prerequisite for the obtainment of pregnancy. Eur J Immunol 2002;32:311-315.

32 Pistoia V, Morandi F, Wang X, Ferrone S: Soluble HLA-G: Are they clinically relevant? Semin Cancer Biol 2007;17:469-479.

33 Apps R, Gardner L, Moffett A: A critical look at HLA-G. Trends Immunol 2008;29:313-321.

-34 Sheu J, Shih Ie M: HLA-G and immune evasion in cancer cells. J Formos Med Assoc 2010;109:248-257.

35 Xu W, Wang Z, Zhang W, Qian K, Li H, Kong D, Li Y, Tang Y: Mutated K-ras activates CDK8 to stimulate the epithelial-to-mesenchymal transition in pancreatic cancer in part via the Wnt/beta-catenin signaling pathway. Cancer Lett 2015;356:613-627.

-36 Xu MZ, Yao TJ, Lee NP, Ng IO, Chan YT, Zender L, Lowe SW, Poon RT, Luk JM: Yes-associated protein is an independent prognostic marker in hepatocellular carcinoma. Cancer 2009;115:4576-4585.

37 Glatzer T, Killig M, Meisig J, Ommert I, Luetke-Eversloh M, Babic M, Paclik D, Bluthgen N, Seidl R, Seifarth C, Grone J, Lenarz M, Stolzel K, Fugmann D, Porgador A, Hauser A, Karlas A, Romagnani C: RORgammat (+) innate lymphoid cells acquire a proinflammatory program upon engagement of the activating receptor NKp44. Immunity 2013;38:1223-1235.

-38 Hansel DE, Rahman A, Wilentz RE, Shih Ie M, McMaster MT, Yeo CJ, Maitra A: HLA-G upregulation in premalignant and malignant lesions of the gastrointestinal tract. Int J Gastrointest Cancer 2005;35:15-23.

-39 Ye SR, Yang H, Li K, Dong DD, Lin XM, Yie SM: Human leukocyte antigen G expression: as a significant prognostic indicator for patients with colorectal cancer. Mod Pathol 2007;20:375-383.

40 Du L, Xiao X, Wang C, Zhang X, Zheng N, Wang L, Zhang X, Li W, Wang S, Dong Z: Human leukocyte antigen-G is closely associated with tumor immune escape in gastric cancer by increasing local regulatory $\mathrm{T}$ cells. Cancer Sci 2011;102:1272-1280.

41 Tuncel T, Karagoz B, Haholu A, Ozgun A, Emirzeoglu L, Bilgi O, Kandemir EG: Immunoregulatory function of HLA-G in gastric cancer. Asian Pac J Cancer Prev 2013;14:7681-7684.

42 Yie SM, Yang H, Ye SR, Li K, Dong DD, Lin XM: Expression of human leukocyte antigen G (HLA-G) correlates with poor prognosis in gastric carcinoma. Ann Surg Oncol 2007;14:2721-2729.

43 Cai MY, Xu YF, Qiu SJ, Ju MJ, Gao Q, Li YW, Zhang BH, Zhou J, Fan J: Human leukocyte antigen-G protein expression is an unfavorable prognostic predictor of hepatocellular carcinoma following curative resection. Clin Cancer Res 2009;15:4686-4693. 


\section{Cellular Physiology Cell Physiol Biochem 2017;44:1828-1841 \begin{tabular}{l|l|l|l|}
\hline DOI: 10.1159/000485819 & 2017 The Author(s). Published by S. Karger AG, Basel \\
\hline
\end{tabular} and Biochemistry

44 Shih Ie M, Davidson B: Pathogenesis of ovarian cancer: clues from selected overexpressed genes. Future Oncol 2009;5:1641-1657.

45 Elliott RL, Jiang XP, Phillips JT, Barnett BG, Head JF: Human leukocyte antigen G expression in breast cancer: role in immunosuppression. Cancer Biother Radiopharm 2011;26:153-157.

-46 de Kruijf EM, Sajet A, van Nes JG, Natanov R, Putter H, Smit VT, Liefers GJ, van den Elsen PJ, van de Velde CJ, Kuppen PJ: HLA-E and HLA-G expression in classical HLA class I-negative tumors is of prognostic value for clinical outcome of early breast cancer patients. J Immunol 2010;185:7452-7459.

-47 Xu Y, Chen L, Xu B, Xiong Y, Yang M, Rui X, Shi L, Wu C, Jiang J, Lu B: Higher Numbers of T-Bet+ TumorInfiltrating Lymphocytes Associate with Better Survival in Human Epithelial Ovarian Cancer. Cell Physiol Biochem 2017;41:475-483.

48 Amodio G, Sales de Albuquerque R, Gregori S: New insights into HLA-G mediated tolerance. Tissue Antigens 2014;84:255-263.

49 Lin A, Yan WH: HLA-G expression in cancers: roles in immune evasion, metastasis and target for therapy. Mol Med 2015.

50 Kang X, Kim J, Deng M, John S, Chen H, Wu G, Phan H, Zhang CC: Inhibitory leukocyte immunoglobulin-like receptors: Immune checkpoint proteins and tumor sustaining factors. Cell Cycle 2016;15:25-40.

51 Carosella ED, Rouas-Freiss N, Roux DT, Moreau P, LeMaoult J: HLA-G: An Immune Checkpoint Molecule. Adv Immunol 2015;127:33-144.

52 Shiroishi M, Tsumoto K, Amano K, Shirakihara Y, Colonna M, Braud VM, Allan DS, Makadzange A, RowlandJones S, Willcox B, Jones EY, van der Merwe PA, Kumagai I, Maenaka K: Human inhibitory receptors Ig-like transcript 2 (ILT2) and ILT4 compete with CD8 for MHC class I binding and bind preferentially to HLA-G. Proc Natl Acad Sci U S A 2003;100:8856-8861.

-53 Gonen-Gross T, Goldman-Wohl D, Huppertz B, Lankry D, Greenfield C, Natanson-Yaron S, Hamani Y, Gilad R, Yagel S, Mandelboim O: Inhibitory NK receptor recognition of HLA-G: regulation by contact residues and by cell specific expression at the fetal-maternal interface. PloS one 2010;5:e8941.

-54 Rajagopalan S, Long EO: Cellular senescence induced by CD158d reprograms natural killer cells to promote vascular remodeling. Proc Natl Acad Sci U S A 2012;109:20596-20601.

55 Rajagopalan S, Long EO: KIR2DL4 (CD158d): An activation receptor for HLA-G. Front Immunol 2012;3:258.

56 Yan WH, Lin A, Chen BG, Zhou MY, Dai MZ, Chen XJ, Gan LH, Zhu M, Shi WW, Li BL: Possible roles of KIR2DL4 expression on uNK cells in human pregnancy. Am J Reprod Immunol 2007;57:233-242.

57 Chang CC, Ferrone S: HLA-G in melanoma: can the current controversies be solved? Semin Cancer Biol 2003;13:361-369.

58 Malmberg KJ, Levitsky V, Norell H, de Matos CT, Carlsten M, Schedvins K, Rabbani H, Moretta A, Soderstrom K, Levitskaya J, Kiessling R: IFN-gamma protects short-term ovarian carcinoma cell lines from CTL lysis via a CD94/NKG2A-dependent mechanism. J Clin Invest 2002;110:1515-1523.

59 Rouas-Freiss N, Bruel S, Menier C, Marcou C, Moreau P, Carosella ED: Switch of HLA-G alternative splicing in a melanoma cell line causes loss of HLA-G1 expression and sensitivity to NK lysis. Int J Cancer 2005;117:114-122.

60 Rouas-Freiss N, Moreau P, LeMaoult J, Carosella ED: The dual role of HLA-G in cancer. J Immunol Res 2014;2014:359748.

-61 Castelli EC, Veiga-Castelli LC, Yaghi L, Moreau P, Donadi EA: Transcriptional and posttranscriptional regulations of the HLA-G gene. J Immunol Res 2014;2014:734068.

62 Maki G, Klingemann HG, Martinson JA, Tam YK: Factors regulating the cytotoxic activity of the human natural killer cell line, NK-92. J Hematother Stem Cell Res 2001;10:369-383.

63 Zeng XC, Zhang T, Huang DH, Wang GY, Chen W, Li H, Zhang J, Fang TL, Zhang Q Chen GH: RNA interfering targeting human leukocyte antigen-G enhanced immune surveillance mediated by the natural killer cells on hepatocellular carcinoma. Ann Clin Lab Sci 2013;43:135-144.

64 Wu D, Kuiaste I, Moreau P, Carosella E, Yotnda P: Rescuing lymphocytes from HLA-G immunosuppressive effects mediated by the tumor microenvironment. Oncotarget 2015;6:37385-37397.

65 Balkwill F: Tumour necrosis factor and cancer. Nat Rev Cancer 2009;9:361-371.

66 Lu Y, Yang W, Qin C, Zhang L, Deng J, Liu S, Qin Z: Responsiveness of stromal fibroblasts to IFN-gamma blocks tumor growth via angiostasis. J Immunol 2009;183:6413-6421.

-67 Ma W, Wu L, Zhou F, Hong Z, Yuan Y, Liu Z: T Cell-Associated Immunotherapy for Hepatocellular Carcinoma. Cell Physiol Biochem 2017;41:609-622. 